\title{
Chemical and biological properties of a sandy loam soil amended with olive mill waste, solid or liquid form, in vitro
}

\author{
Nikolaos Gougoulias ${ }^{1 \dagger}$, Ioannis Vagelas ${ }^{1 \dagger}$, Alexandros Papachatzis ${ }^{1 \dagger}$, Eleftheria Stergiou ${ }^{1 \dagger}$, Nikolaos Chouliaras $^{1 * \dagger}$ \\ and Adamantia Chouliara ${ }^{2}$
}

\begin{abstract}
Background: The profitable use of the large amounts of olive oil mill wastes produced in Greece, as source of soil organic matter, might be probably beneficial to soil microorganism activity.

Results: A high rate of organic matter biodegradation was observed in soil samples amended with the liquid form of olive mill wastewater, whereas the vice versa results were obtained with the solid form. When the soil was amended with a mixture of both olive mill waste forms, liquid $(L)$ and solid $(S)$, the organic matter of the solid waste (S) showed a well-improved biodegradation; the available forms of P, K, Zn, Mn, and Cu were increased, especially in treatments where the olive mill wastewater, liquid form, was threefold in comparison to the solid form. Moreover, the soil amended with the solid (S) form of olive mill waste reduced bacterial growth significantly, and both waste forms act negative impacts to soil-borne fungi belonging to the genus Rhizopus.

Conclusions: The results of this work demonstrated the high potential of olive mill waste, solid or liquid form, added to sandy loam soil in an incubation experiment in vitro. The better results for soil quality were obtained when a combining mixture of these materials was added in the ratio 1:3 (solid/liquid).
\end{abstract}

Keywords: Olive mill waste; Soil organic matter biodegradation; Soil microflora; Soil chemical properties

\section{Introduction}

The organic matter as a soil fraction is regulating the biological activity of soils, so a satisfactory content in organic material dominates the soil fertility (Economou et al. 1980; Chouliaras et al. 1998; Gougoulias et al. 2010).

Very important amounts of olive mill waste are produced in olive cultivation areas, ranging between $1.75 \times 10^{6}$ and $2.25 \times 10^{6}$ tons/year of olive mill wastewater for Greece (Kyriazopoulos 2005); then, the profitable use of these organic materials as soil amendments are beneficial both to soil improvement and environmental protection.

Numerous methods are used for the treatments of olive mill waste; then, the respective products added to the soil act various effects on soil properties and plant growth

\footnotetext{
* Correspondence: chouliar@teilar.gr

${ }^{\dagger}$ Equal contributors

'Department of Crop Production, Technological Education Institution of Thessalia, Larissa 41110, Greece

Full list of author information is available at the end of the article
}

(Ouzounidou et al. 2010). The waste could be applicable as composted material, while the raw waste could have beneficial effects concerning time and cost (Lopez-Pineiro et al. 2010).

The beneficial effects of these amendments are related to soil organic matter increase (Ordonez-Fernadez et al. Ordonez-Fernadez and Carbonnell-Bojollo 2010) then, consequently, to soil chemical and physical property improvement (Nikolaos et al. 2011). According to LopezPineiro et al. (2011), successive applications of the de-oiled two-phase olive mill waste on soil as amendment may be an effective management practice for controlling their ability to increase $\mathrm{P}$ availability. The two-phase olive mill waste application to olive grove soil increased organic carbon, total $\mathrm{N}$, available $\mathrm{P}$ and $\mathrm{K}$, and in general, increased olive production (López-Piñeiro et al. 2008).

The soil content in organic matter, as well as that added to soils, affects significantly the physical properties of soil; it is useful to quote that the collapse potentials of soils inundated by oil is always less than when inundated by 
water (Labib et al. 2009), and according to López-Piñeiro et al. (2008), the olive mill waste application to olive grove soil increased soil aggregation stability.

The effect of this olive mill waste material on soil microbial activity was also assessed (Kotsou Maria et al. 2004; Hammed et al. 2008; Saadi et al. 2007). Moreover, the antimicrobial effect, probably due to polyphenolic compounds, occurring in olive mill wastewater against fungi was demonstrated by Vagelas et al. (2009a, b). Furthermore, according to Abid et al. (2007), water thermophilic bacteria as well as actinomycetes dominated over eumycetes during composting of the olive mill waste.

Soil amendment using compost derived from olive mill by-products can be an important agricultural practice for supporting and stimulating soil microorganisms and, at the same time, for re-using these by-products, so avoiding their negative environmental impact (Casacchia et al. 2012); furthermore, according to Barjea et al. (2013), liquid and solid olive oil mill waste treatment by composting in a mixture with the organic part of municipal solid waste and rock phosphate opens the way to agricultural spreading. The aim of this work was to examine the effects of biological and chemical properties on soil caused by the rate and the nature of the solid waste or olive mill wastewater in vitro.

\section{Methods}

The study was conducted in two incubation experiments. During the first experiment, the waste was tested either in liquid or solid form, added separately to the soil. During the second experiment, adequate mixtures of both forms were tested.

\section{Incubation}

In the incubator, the treatments were prepared in triplicates and kept at $28^{\circ} \mathrm{C}$ for a period of 15 weeks, for each experiment. During the first 3 weeks for each incubation period, the moisture was maintained at two thirds of field capacity, but for the next 3 weeks, the soils were left to dry. This process was repeated until the end of the incubation period. According to $\mathrm{Wu}$ and Brookes (2005), the alternation of drying and rewetting soil samples enhances mineralization of both soil biomass organic matter and non-biomass organic matter.

\section{First experiment - separate application of each waste form to soil}

In this study, 13.51, 27.03, and $40.54 \mathrm{~g}$ of solid waste material containing 2.5, 5.0, and $7.5 \mathrm{~g}$ of organic matter were added to $50 \mathrm{~g}$ of air-dried, light-textured soil, respectively, which was poor in organic matter. All these materials - soil and waste - were obtained from the region of Larissa (Greece, Table 1). The amounts 41.7, 83.3, and $125.0 \mathrm{~g}$ of olive mill wastewater containing 2.5, 5.0 , and $7.5 \mathrm{~g}$ of organic matter, respectively, were also added into $50 \mathrm{~g}$ of the same soil.

\section{Water-soluble extracts during incubation}

In the middle of the incubation period, all treatments of the first experiment were leached with distilled water $\left(1: 5\left(\mathrm{soil} / \mathrm{H}_{2} \mathrm{O}\right)\right)$, and all water extracts were collected to be analyzed in order to approach the ecological effect of rainfall in natural leaching conditions.

Table 1 Chemical properties of the soil, solid waste, and olive mill wastewater

\begin{tabular}{|c|c|c|c|}
\hline & \multicolumn{3}{|c|}{ Material } \\
\hline & Soil (Calcaric Fluvisol, $10 \mathrm{~cm}$ in depth) & Solid waste (wet basis) & Olive mill wastewater (wet basis) \\
\hline Texture & Loamy sand & - & - \\
\hline $\begin{array}{l}\text { Cation exchange capacity } \\
\left(\mathrm{cmol} \mathrm{kg}^{-1}\right)\end{array}$ & 19 & 102 & - \\
\hline $\mathrm{pH}$ & 8.1 & 4.90 & 5.10 \\
\hline Organic matter $\left(\mathrm{g} \mathrm{kg}^{-1}\right)$ & 5.0 & 185.0 & 60 \\
\hline $\mathrm{CaCO}_{3}\left(\mathrm{~g} \mathrm{~kg}^{-1}\right)$ & 86 & - & - \\
\hline $\begin{array}{l}\text { Electrical conductivity, extract } \\
\left(\mathrm{dS} \mathrm{m}^{-1}\right)\end{array}$ & 0.5 (one part soil + five parts $\mathrm{H}_{2} \mathrm{O}$ ) & 0.91 (one part waste + five parts $\mathrm{H}_{2} \mathrm{O}$ ) & 1.84 (raw waste) \\
\hline Total N $\left(\mathrm{g} \mathrm{kg}^{-1}\right)$ & 0.4 & 0.82 & 0.55 \\
\hline Total P $\left(\mathrm{mg} \mathrm{kg}^{-1}\right)$ & 272 & 483 & 308 \\
\hline Total $\mathrm{K}\left(\mathrm{mg} \mathrm{kg}^{-1}\right)$ & 207 & 770 & 3,900 \\
\hline Total Mn ( $\left.\mathrm{mg} \mathrm{kg}^{-1}\right)$ & - & 14 & 68 \\
\hline Total Cu $\left(\mathrm{mg} \mathrm{kg}^{-1}\right)$ & - & 122 & 13.7 \\
\hline Total Zn (mg kg $\left.{ }^{-1}\right)$ & - & 21 & 6.2 \\
\hline
\end{tabular}

Wet solid and aqueous olive waste produced through a three-phase decanter process from an olive mill located in Larissa was used in this work. The solid wastes or olive husk is a mixture of olive pulp and olive kernel, while the aqueous olive waste (olive mill wastewater) is the water added during preparation and oil extraction process (olive fruit washing, malaxation, and centrifugation). One three-phase centrifuge-type oil mill produces approximately $500 \mathrm{~kg}$ of wet solid waste, and 1,200 kg of olive mill waste water is derived per $1,000 \mathrm{~kg}$ of processed olives. 


\section{Second experiment - application of solid and liquid waste mixture to soil}

This experiment was established based on the data of the first experiment; then, an adequate mixture of the two waste forms was chosen in order to be tested. In this study, $24.39 \mathrm{~g}$ of solid waste $+8.13 \mathrm{~g}$ of olive mill wastewater $(3: 1(\mathrm{~S} / \mathrm{L})), 20.4 \mathrm{~g}$ of solid waste $+20.4 \mathrm{~g}$ of olive mill wastewater $(1: 1(\mathrm{~S} / \mathrm{L}))$, and $13.7 \mathrm{~g}$ of solid waste $+41.1 \mathrm{~g}$ of olive mill wastewater $(1: 3(\mathrm{~S} / \mathrm{L}))$ were added to $50 \mathrm{~g}$ of the same soil, respectively. Each mixture contained $50 \mathrm{~g}$ of organic matter.

\section{Methods of analyses}

At the end of the incubation period, soil samples were analyzed using the following methods which are referred by Page et al. (1982):

1. Organic carbon was analyzed by chemical oxidation with $1 \mathrm{~mol} \mathrm{~L}^{-1} \mathrm{~K}_{2} \mathrm{Cr}_{2} \mathrm{O}_{7}$ and titration of the remaining reagent with $0.5 \mathrm{~mol} \mathrm{~L}^{-1} \mathrm{FeSO}_{4}$. Total humus compounds (humic + fulvic acids) were extracted at $\mathrm{pH} 12$ with $\mathrm{NaOH}$, and humic acids were precipitated at $\mathrm{pH} 2$ with $\mathrm{HCl}$, according to fractionation of soil organic matter protocol proposed by Chouliaras et al. (1975). The soil organic carbon contents were transformed into organic matter contents by multiplying by 1.724 , which is an experimental factor, as reported by Hesse (1972).

2. Both ammonium and nitrate nitrogen were extracted with $0.5 \mathrm{~mol} \mathrm{~L}^{-1} \mathrm{CaCl}_{2}$ and estimated by distillation in the presence of $\mathrm{MgO}$ and Dewarda alloy, respectively.

3. Organic phosphorus was measured after mineralization by combustion of the soil sample and subtraction of the mineral phosphorus amounts, which had previously been estimated in the laboratory. The mineral amounts were extracted with $1 \mathrm{~mol} \mathrm{~L}^{-1} \mathrm{H}_{2} \mathrm{SO}_{4}$, and all forms were measured by spectroscopy.

4. Available P forms (Olsen P) were extracted with $0.5 \mathrm{~mol} \mathrm{~L}^{-1} \mathrm{NaHCO}_{3}$ and measured by spectroscopy.

5. Exchangeable forms of potassium were extracted with $1 \mathrm{~mol} \mathrm{~L}^{-1} \mathrm{CH}_{3} \mathrm{COONH}_{4}$ and measured by flame photometer.
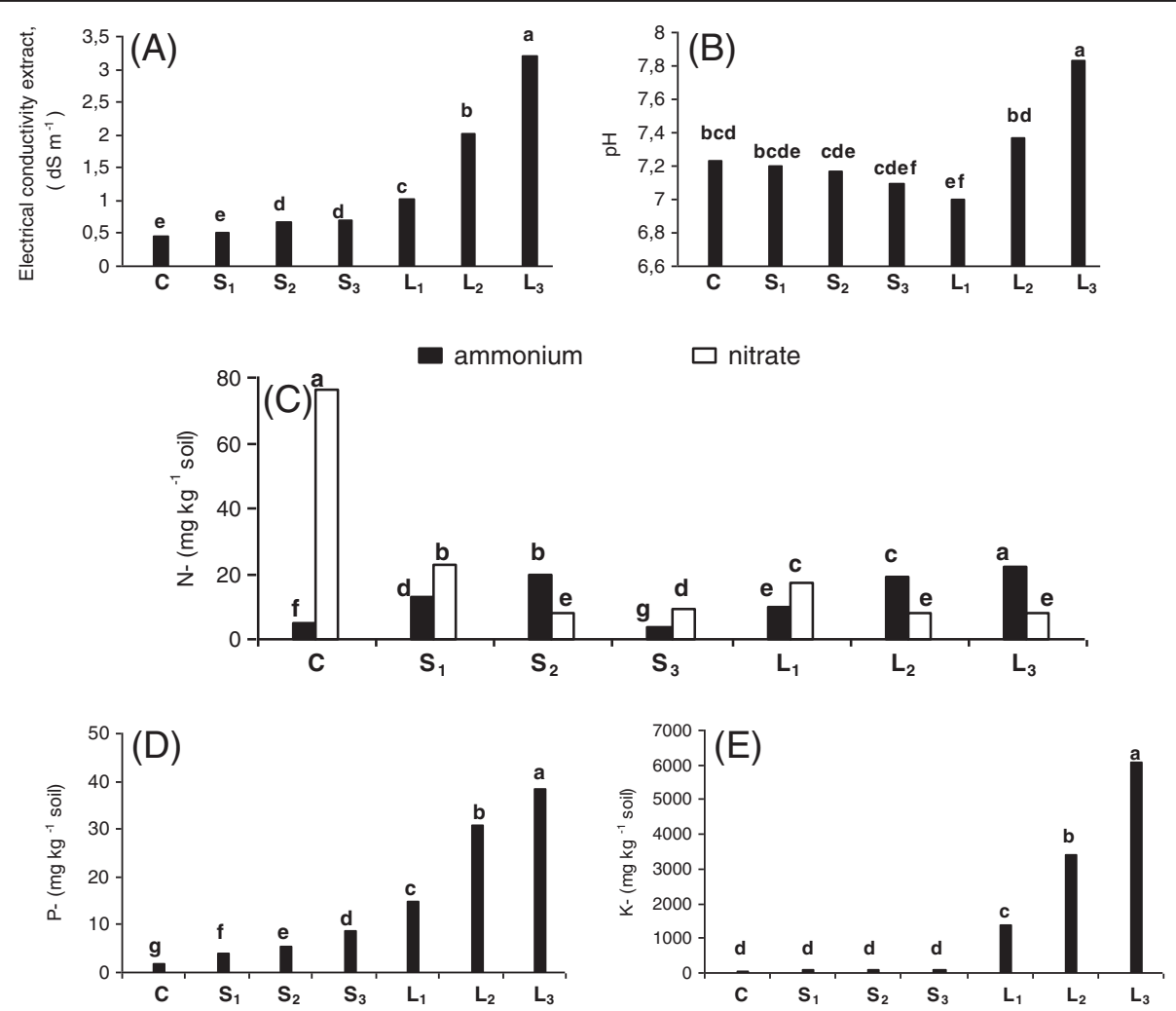

Figure 1 Chemical properties of water extracts. Taken during incubation time after adding solid waste or olive mill wastewater on soil samples. (A) Electrical conductivity, (B) soil pH, (C) ammonium and nitrate contents, (D) water-soluble phosphorus, and (E) water-soluble potassium. Bars in each characteristic of each graph with the same letter do not differ significantly according to Tukey's test $(P=0.05)$. C, control (soil); $S_{1}, S_{2}$, or $S_{3}$, solid waste $13.51,27.03$, or $40.54 \mathrm{~g}$ per $50 \mathrm{~g}$ of soil, respectively; $L_{1}$, $L_{2}$, or $L_{3}$, olive mill wastewater $41.7,83.4$, or $125.1 \mathrm{~g}$ per $50 \mathrm{~g}$ of soil, respectively. 
6. Available forms of $\mathrm{Mn}, \mathrm{Zn}$, and $\mathrm{Cu}$ were extracted with DTPA (diethylene triamine pentaacetic acid $0.005 \mathrm{~mol} \mathrm{~L}^{-1}+\mathrm{CaCl}_{2} 0.01 \mathrm{~mol} \mathrm{~L}^{-1}+$ triethanolamine $0.1 \mathrm{~mol} \mathrm{~L}^{-1}$ ) and measured by atomic absorption.

\section{Soil microflora}

To investigate the effect of added material on the soil microflora (bacterial and fungal communities), a small amount of soil was spread onto potato dextrose agar plates and incubated for 2 days at $25^{\circ} \mathrm{C}$ in darkness. After the incubation period, the number of bacterial colonies formed was counted. The same plates were further incubated as above for another 6 days. After the incubation period, the emerged fungi per plate and per treatment were recognized under the microscope.

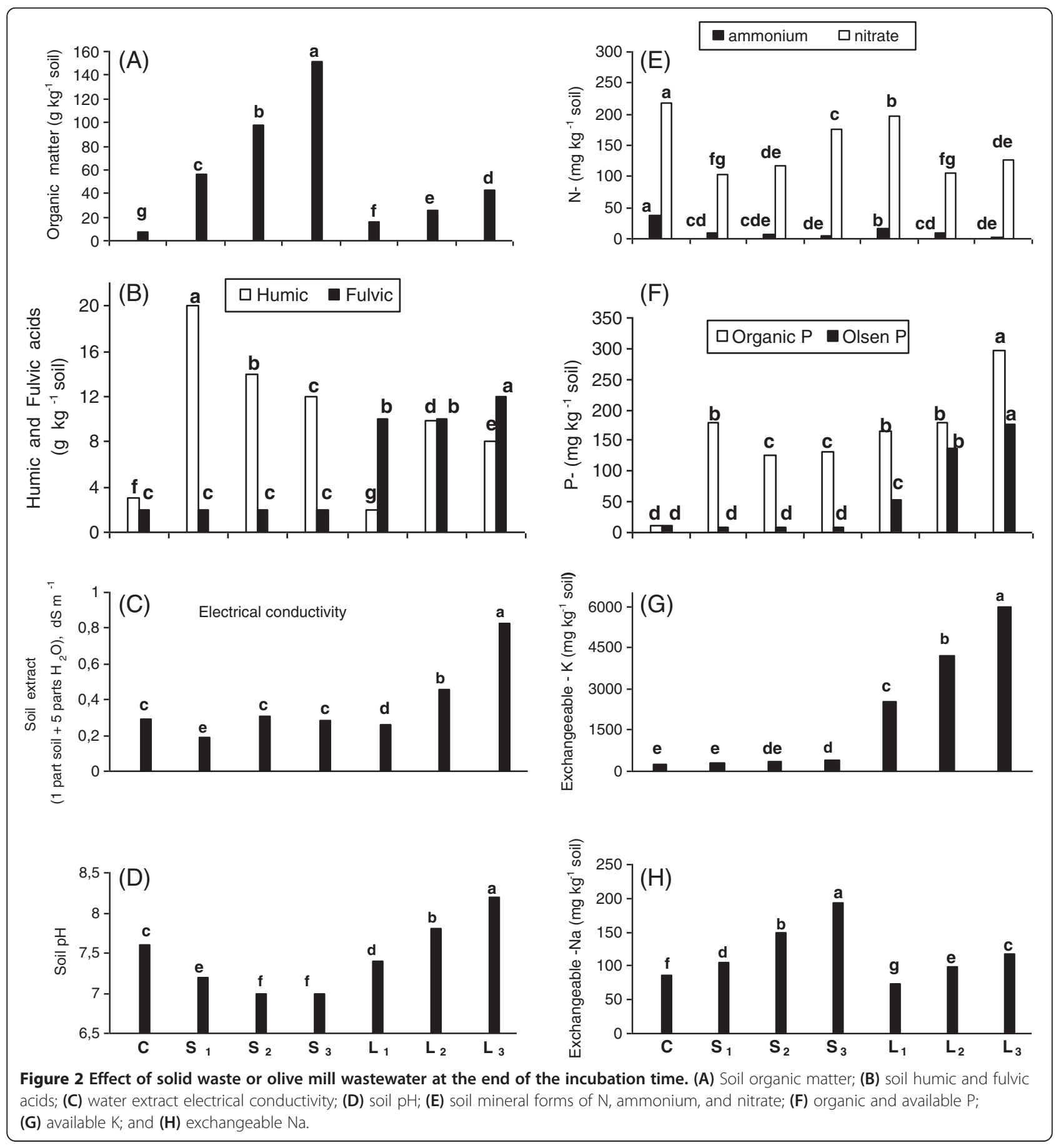




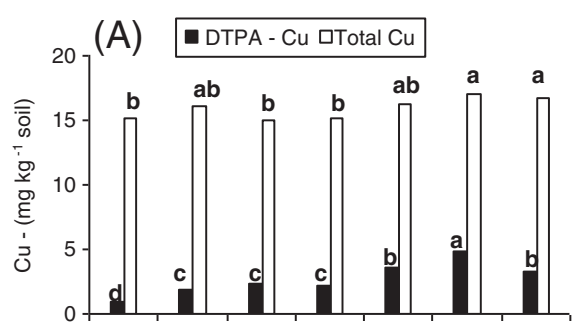

(B) DTPA-Zn DTotal Zn

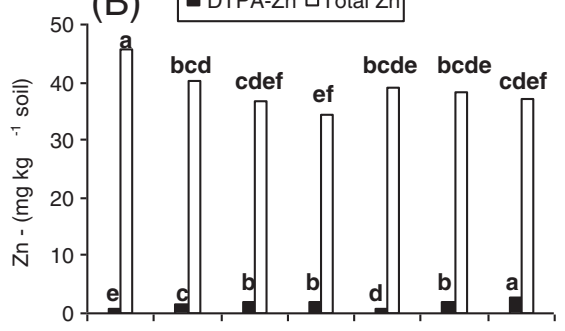

(C)

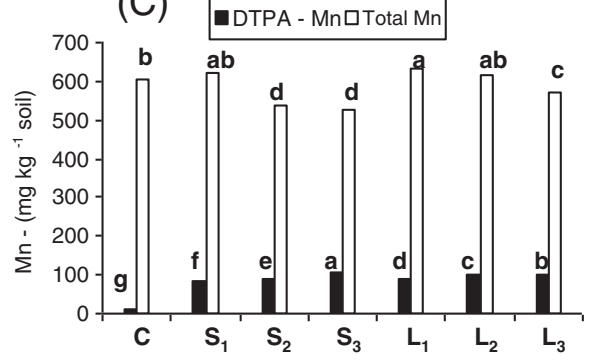

(D)

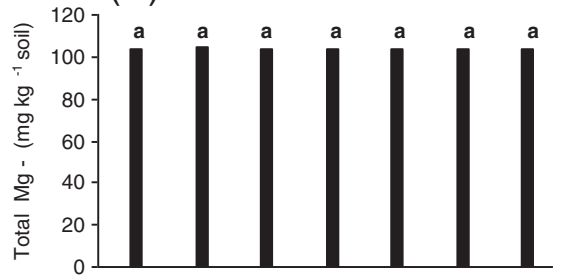

$(\mathrm{E})$
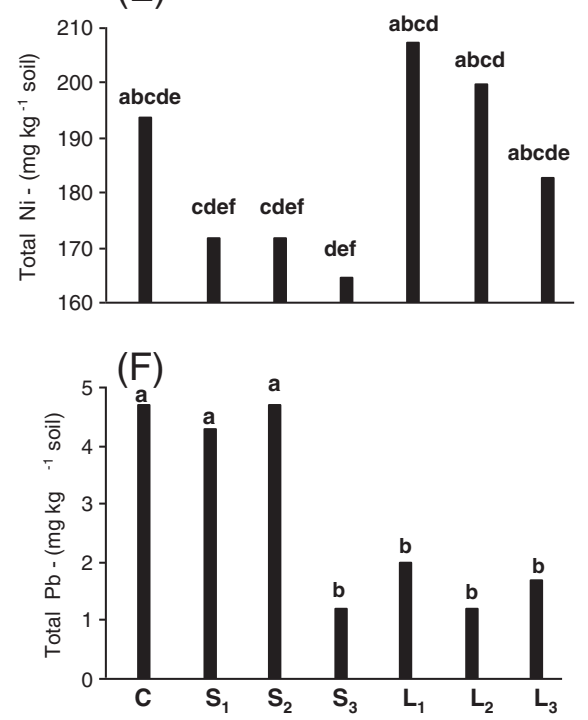

Figure 3 Effect of solid waste or olive mill wastewater added to soil on total and available forms. $\mathrm{Cu}$ (A), $\mathrm{Zn}$ (B), and Mn (C), or of total $\mathrm{Mg}(\mathbf{D}), \mathrm{Ni}(\mathbf{E})$, and $\mathrm{Pb}(\mathbf{F})$.

\section{Statistical analyses}

The experiment was repeated, and the completely randomized design with three replications was used. Tukey's procedures were used to detect and separate the mean treatment differences at $P=0.05$. Statistical analyses were performed by the statistical program Ryan et al. (2005).

\section{Results}

First experiment - separate application of each waste form to soil

Water extracts

The studied water extracts, taken by leaching the soil treatments in the middle of the incubation period, showed a significant increase of soil salinity and alkalinity in all the

Table 2 Effect of olive oil mill waste on the number of bacterial colonies and fungi

\begin{tabular}{|c|c|c|c|c|c|c|c|}
\hline & \multirow[t]{3}{*}{ C } & \multicolumn{6}{|c|}{ Treatments } \\
\hline & & \multicolumn{3}{|c|}{ Solid waste mill } & \multicolumn{3}{|c|}{ Olive mill wastewater } \\
\hline & & S1 & S2 & S3 & L1 & L2 & L3 \\
\hline Number of bacterial colonies & $121 b$ & $112 \mathrm{a}, \mathrm{b}$ & $109 a, b$ & $96 a, b$ & $70 \mathrm{a}$ & $124 b$ & $301 \mathrm{C}$ \\
\hline \multicolumn{8}{|l|}{ Microorganisms } \\
\hline Fusarium species & + & - & - & +++ & - & - & +++ \\
\hline Aspergillus species & + & - & + & - & - & ++ & - \\
\hline Mucor species & ++ & +++ & +++ & - & - & - & - \\
\hline Rhizopus species & +++ & - & - & - & - & - & - \\
\hline Acremonium species & - & + & - & - & - & - & + \\
\hline
\end{tabular}

Columns with the same letters ( $a, b$, and c) do not differ significantly according to Tukey's test $(P=0.005)$. Fungal mycelia were graded from $+($ weak growth) to +++ (strong growth), and - (not detected). $C$, control (soil); $S_{1}, S_{2}$, or $S_{3}$, solid waste $13.51,27.03$, or $40.54 \mathrm{~g}$ per $50 \mathrm{~g}$ of soil, respectively; $L_{1}$, $L_{2}$, or $L_{3}$, olive mill wastewater $41.7,83.4$, or $125.0 \mathrm{~g}$ per $50 \mathrm{~g}$ of soil, respectively. 
samples amended with olive mill wastewater; in these water extract treatments, a significant elevation in $\mathrm{P}$ and $\mathrm{K}$ water-soluble forms was also attested in comparison with the control (Figure 1).

\section{End of incubation period}

The organic contents of soil treated at the end of the incubation period proved a high percentage of organic matter biodegradation, about $>60 \%$, for all the samples amended with soluble waste. On the contrary, a strong resistance to biodegradation has been shown by samples treated with solid waste; a significant increase of salinity and alkalinity was also revealed for treatments with the two upper rates of liquid applications, and available forms of $\mathrm{P}$ and $\mathrm{K}$ were also found significantly increased in these treatments with olive mill wastewater (Figure 2).
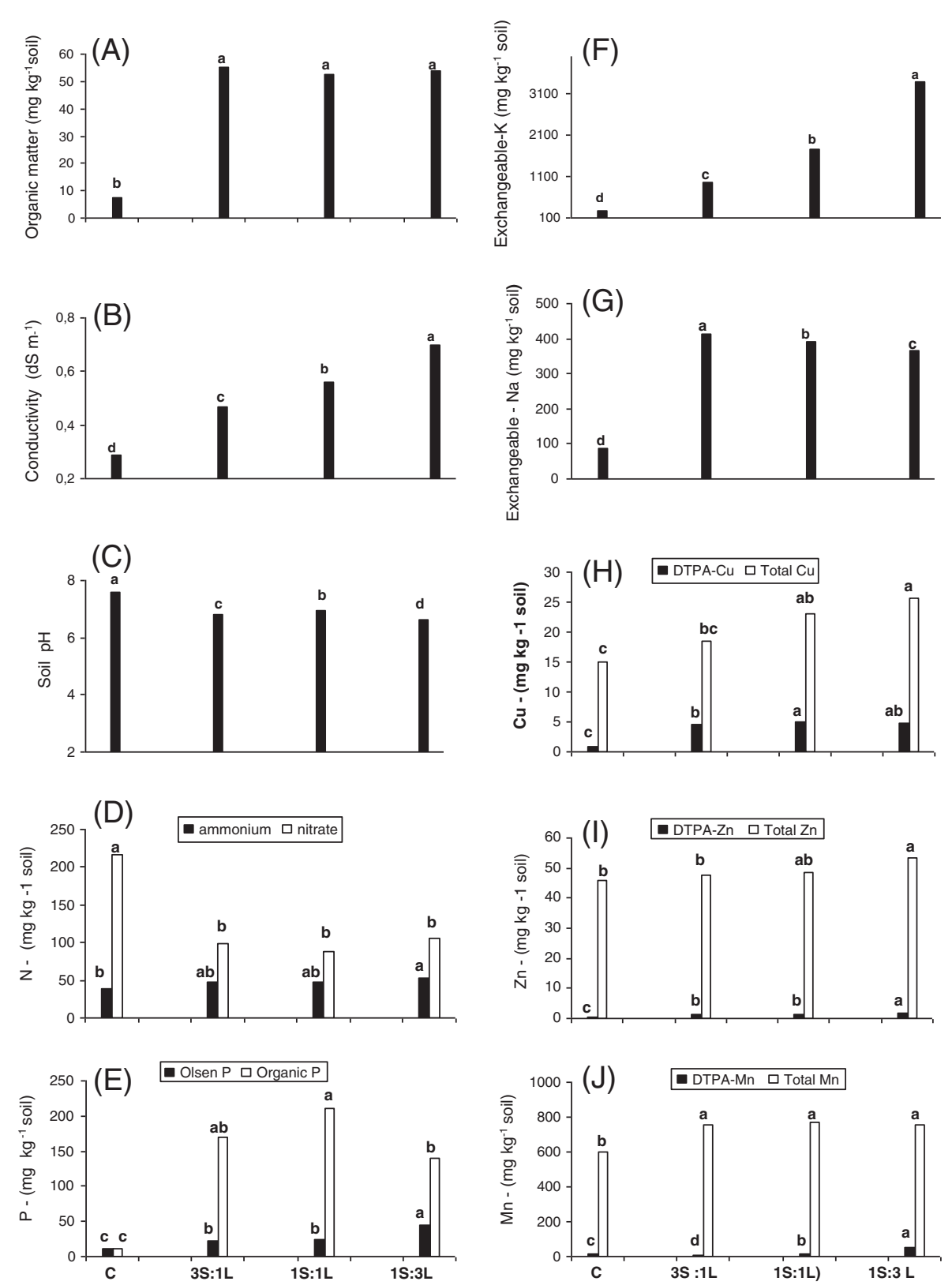

Figure 4 Effect of different mixtures of solid waste and olive mill wastewater added to soil. On organic matter contents (A), on electrical conductivity of soil extract, 1:5 (soil// $\left.\mathrm{H}_{2} \mathrm{O}\right)(\mathbf{B})$, on soil pH (C), on nitrogen contents (D), on $\mathbf{P}$ form contents $(\mathbf{E})$, on exchangeable $\mathrm{K}$ contents $(\mathbf{F})$, on exchangeable Na contents (G), on Cu forms (H), on Zn forms (I), and on Mn forms (J). C, control (soil); $24.39 \mathrm{~g}$ of solid waste $+8.13 \mathrm{~g}$ of olive mill wastewater $(3: 1(S / L))$, $20.4 \mathrm{~g}$ of solid waste $+20.4 \mathrm{~g}$ of olive mill wastewater $(1: 1(\mathrm{~S} / \mathrm{L}))$, and $13.7 \mathrm{~g}$ of solid waste $+41.1 \mathrm{~g}$ of olive mill wastewater $(1: 3(\mathrm{~S} / \mathrm{L}))$ were added correspondingly to $50 \mathrm{~g}$ of the same soil. Bars in each characteristic of each graph with the same letter do not differ significantly according to Tukey's test $(P=0.05)$. 
The $\mathrm{NO}_{3}^{-}$content of all treatments at the end of the incubation period is higher in comparison with $\mathrm{NH}_{4}^{+}$, but that $\left(\mathrm{N}-\mathrm{NO}_{3}^{-} / \mathrm{N}-\mathrm{NH}_{4}^{+}\right)$ratio is lower in the case of water leaching extracts, taken earlier than the end of the incubation period; then, nitrification process is unachieved. A significant increase for P organic synthesis was also revealed for all treatments.

A significant elevation in available forms for $\mathrm{Cu}, \mathrm{Mn}$, and $\mathrm{Zn}$ in comparison to the control for all treatments was attested, and the increase of exchangeable $\mathrm{Na}$ did not cause any sodicity risk for soil (Figure 3).

The humic acid contents are always predominating in comparison with fulvic acid contents for treatments with solid waste, which is a very ligneous material (Figure 2). According to our results, soil bacterial numbers increased significantly by L3 (upper rate of olive mill wastewater, Table 2). On the contrary, S1, S2, and S3 treatments (solid waste) reduced total soil bacterial number as well as olive waste of both forms acted a significant negative effect to the genus Rhizopus.

\section{Second experiment - application of solid and olive mill wastewater mixture to soil}

The mixture of these two sorts of waste materials added to soil produced a well-decomposed organic mixture during incubation, concerning organic matter for both solid or olive mill wastewater; the organic matter of these mixtures is decomposed about $>40 \%$; then, the organic matter of solid waste is better decomposed under the effect of the olive mill wastewater, in comparison to the results of the first experiment where solid waste was separately added to soil. The salinity was further increased in the case of the mixture 1:3 (S/L), but soil $\mathrm{pH}$ was slightly affected in all treatments. At the end of the incubation period, relatively high amounts of $\mathrm{N}-\mathrm{NH}_{4}^{+}$forms yet existed, but $\mathrm{N}-\mathrm{NO}_{3}^{-}$ forms predominate in comparison to $\mathrm{N}_{-} \mathrm{NH}_{4}^{+}$forms.

Organic $\mathrm{P}$ content increased significantly in all treatments, and available forms of $\mathrm{P}, \mathrm{K}$, and $\mathrm{Mn}$ were increased especially at the mixture 1:3 (S/L); also, the available forms of $\mathrm{Cu}$ and $\mathrm{Zn}$ increased for all treatments. The increase of exchangeable $\mathrm{Na}$ did not cause any sodicity risk for soil by these mixtures either (Figure 4).

Moreover, it seems that olive mill waste (both phases) acts a significant impact on soil-borne fungi belonging to the genus Rhizopus (Tables 2 and 3), but it might have allowed the growth of some fungi species of Aspergillus and Fusarium (Tables 2 and 3).

\section{Discussion}

When the two kinds of waste were added separately, a strong resistance to biodegradation has been proved by solid waste; the organic matter of solid waste is better decomposed under the effect of the olive mill wastewater, when the two waste sorts are added together. A probable explanation for that effect could be the higher content in fulvic acids of olive mill wastewater, and these more labile compounds are estimated
Table 3 Effect of solid waste and olive mill wastewater on the number of bacterial colonies and fungi

\begin{tabular}{lllll}
\hline & Control & \multicolumn{3}{c}{ Treatments } \\
\cline { 3 - 5 } & & $3: 1$ (S/L) & $\mathbf{1 : 1}(\mathbf{S} / \mathrm{L})$ & $\mathbf{1 : 3}(\mathbf{S} / \mathbf{L})$ \\
\hline Number of bacterial colonies & $121 \mathrm{c}$ & $50 \mathrm{a}$ & $74 \mathrm{~b}$ & $38 \mathrm{a}$ \\
Microorganisms & & & & \\
Fusarium species & + & - & ++ & ++ \\
Aspergillus species & + & +++ & - & - \\
Mucor species & ++ & + & ++ & ++ \\
Rhizopus species & +++ & - & - & -
\end{tabular}

Columns with the same letters $(a, b$, and $c)$ do not differ significantly according to Tukey's test $(P=0.005)$. Fungal mycelia were graded from + (weak growth) to +++ (strong growth), and - (not detected). C, control (soil), $24.39 \mathrm{~g}$ of solid waste $+8.13 \mathrm{~g}$ of olive mill wastewater (3:1 (S/L), $20.4 \mathrm{~g}$ of solid waste $+20.4 \mathrm{~g}$ of olive mill wastewater $(1: 1(\mathrm{~S} / \mathrm{L}))$, and $13.7 \mathrm{~g}$ of solid waste $+41.1 \mathrm{~g}$ of olive mill wastewater $(1: 3(\mathrm{~S} / \mathrm{L}))$ were added correspondingly to $50 \mathrm{~g}$ of the same soil.

as more biodegradable by soil microflora, (Jacquin and Chouliaras 1976). The salinity elevation is more affected by olive mill wastewater application, and it is important to remark the increased presence of available forms of $\mathrm{P}, \mathrm{K}, \mathrm{Zn}$, $\mathrm{Mn}$, and $\mathrm{Cu}$ in the soils amended with the mixture of solid + olive mill wastewater, in the ratio 1:3 (S/L).

Waste addition might be attributed to the increase of availability of heavy metals, such as $\mathrm{Zn}$ and $\mathrm{Cu}$, which reduced bacterial growth. Toxicity of these heavy metals ( $\mathrm{Zn}$ and $\mathrm{Cu}$ ) to the organism (soil bacterial community) is well known (Frostegard et al. 1993; Giller et al. 1998; Novak et al. 2005). Moreover, this study showed that the soil amended with 1:3 (S/L) mixture increased the growth of fungi belonging to the subdivision Deuteromicotina, class Deuteromycetes (Fusarium) and the fungus belonging to the genus Mucor (class Zygomycetes); these soil fungi are resistant to toxic metals, such as $\mathrm{Zn}$ and $\mathrm{Cu}$ (Kao et al. 2006), and it seems that in the present study, these fungi species increased the exchangeable $\mathrm{K}$ in soil. According to the literature, microorganisms like fungi species Aspergillus and Fusarium are known for their resistance to heavy metals (Kapoor et al. 1999; Ahmad et al. 2005; Bishnoi and Garima 2005). Based on this, we can conclude that soil amended with 1:3 (S/L) olive mill waste mixture could be an alternative way to chemical control.

\section{Conclusions}

The organic matter of solid waste is better decomposed under the effect of the olive mill wastewater, when the two waste sorts are added together; when the soil is amended with the mixture of solid + olive mill wastewater on soil, in the ratio 1:3 $(\mathrm{S} / \mathrm{L})$, an important increase of available forms of $\mathrm{P}, \mathrm{K}, \mathrm{Zn}, \mathrm{Mn}$, and $\mathrm{Cu}$ was remarked. As far as it concerns soil microflora, solid waste acted a limitation effect to total soil bacterial number as well as olive waste of both forms acted a significant negative effect to the genus Rhizopus. 


\section{Abbreviations}

S: Solid material of olive mill waste; L: liquid material of olive mill waste.

\section{Competing interests}

The authors declare that they have no competing interests.

\section{Authors' contributions}

NG, first author, principal contribution to the work. All authors read and approved the final manuscript.

\section{Acknowledgements}

The research is realized based on equipment disposed by "Soil science lab and Plant Pathology lab, of Department of Crop Production, TEl of Thessalia (Greek Ministry of Education)

\section{Author details}

${ }^{1}$ Department of Crop Production, Technological Education Institution of Thessalia, Larissa 41110, Greece. ${ }^{2}$ Informatics' Scientist (MSc), data processing laboratory Assistant in the Department of Public Engineering, Technological Education Institution of Thessalia, Larissa 41110, Greece.

\section{Received: 20 November 2012 Accepted: 14 July 2013} Published: 08 Aug 2013

\section{References}

Abid N, Chamkha M, Godon JJ, Sayadi S (2007) Involvement of microbial populations during the composting of olive mill wastewater sludge. Environ Technol 28:751-760

Ahmad I, Zafar S, Ahmad F (2005) Heavy metal biosorption potential of Aspergillus and Rhizopus sp. isolated from wastewater treated soil. J Appl Sci Environ 9:123-126

Barjea F, Felsa LE, Hajjoujia HE, Wintertonb P, Hafidia M (2013) Biodegradation of organic compounds during co-composting of olive oil mill waste and municipal solid waste with added rock phosphate. Environ Technol. doi:10.1080/09593330.2013.796009

Bishnoi NR, Garima (2005) Fungus - an alternative for bio-remediation of heavy metal containing waste water: a review. J Scientific \& Industrial Res 64:93-100

Casacchia T, Sofo A, Zelasco S, Perri E, Toscano P (2012) In situ olive mill residual co-composting for soil organic fertility restoration and by-product sustainable reuse. Ital J Agron 7(e-23):167-170

Chouliaras N, Védy JC, Jacquin F, Portal JM (1975) Fractionnement et caractérisation de la matière organique dans les Rendzines. Bull ENSAIA XVII (I):65-74

Chouliaras N, Vedy JC, Tsadilas C (1998) Speciation of phosphate, Fe, Zn, Mn, $\mathrm{Cu}$ and their availability in soils amended with sewage sludge. Poster presentation and publication. In: Proceedings of the 16th world congress of soil science., Montpellier, pp 1-8

Economou E, Chouliaras N, Jacquin F, Sdoucos A (1980) Interférence entre minéralisation du carbone et assimilabilité des phosphates naturels en sols acides. Bull. XXII, ENSAIA, pp 119-123

Frostegard A, Tunlid A, Baath E (1993) Phospholipid fatty acid composition, biomass, and activity of microbial communities from two soil types experimentally exposed to different heavy metals. Appl Environ Microbiol 59:3605-3617

Giller KR, Witter E, Grath Mc SP (1998) Toxicity of heavy metals to microorganisms and microbial processes in agricultural soils: a review. Soil Biol Biochem 30:1389-1414

Gougoulias N, Vagelas I, Vasilakoglou I, Gravanis F, Louka A, Wogiatzi E, Chouliaras N (2010) Comparison of neem and oregano with thiram on organic matter decomposition of a sand loam soil amended with compost, and on soil biological activity. J Sc Food Agric 90:286-290

Hammed K, Turk M, Assaf T, Tawaha AMAL (2008) Effects of application of olive mill by-products on chickpea yield and their symbiosis with mycorhizal fungi under arid conditions. Int J Plant production 2(4):341-352

Hesse PR (1972) A textbook of soil chemical analysis. Chemical Publishing Company, Revere, p 520

Jacquin F, Chouliaras N (1976) Evolution de la matière organique dans une rendzine et son interférence sur une classification génétique des humus. Bull AFES 4:241-246
Kao PH, Huang CC, Hseu ZY (2006) Response of microbial activities to heavy metals in a neutral loamy soil treated with biosolid. Chemosphere 64:63-70

Kapoor A, Viraraghavan T, Cullimore DR (1999) Removal of heavy metals using the fungus Aspergillus niger. Bioresourse Technol 70:95-104

Maria K, loanna M, Katia L, Chatzipavlidis I, Balis K, Adamantini K (2004) The effect of olive oil mill wastewater (OMW) on soil microbial communities and suppressiveness against Rhizoctonia solani. Appl Soil Ecol 26:113-121

Kyriazopoulos C (2005) The biodegradation of olive mill wastewater after application on soil. University of Patras, MSc dissertation, p 111

Labib MS, Mansour MA, Baligh FA (2009) Effect of oil on the behavior of collapsible soil. In: Proceedings of the 17th international conference on soil mechanics and geotechnical engineering: the academia and practice of geotechnical engineering. , Alexandria, pp 809-811

López-Piñeiro AA, Rato Nunes JM, Barreto C (2008) Short and medium-term effects of two-phase olive mill waste application on olive grove production and soil properties under semiarid mediterranean conditions. Bioresour Technol 99:7982-7987

Lopez-Pineiro A, Cabrera D, Albaran A, Pena D (2010) Cumulative and residual effects of de-oiled two phase olive mill waste application to soil on diuron sorption, leaching, degradation, and persistence. Chemosphere 78:139-146

Lopez-Pineiro A, Albaran A, Cabrera D, Pena D, Nunes JMR, Rato JM (2011) Deoiled two phase olive mill waste application impact on phosphorus sorption and fractionation in a Mediterranean soil under olive production. Soil Sci 176:22-32

Nikolaos N, Panagiotis N, Glykeria G (2011) Evaluation of olive waste compost as a soil amendment for Cynodon dactylon turf establishment, growth, and anchorage. HortSci 46:937-945

Novak JM, Watts DW, Stone KC (2004) Copper and zinc accumulation, profile distribution, ane crop removal in coastal plain soils receiving long-term, intensive applications of swine manure. Trans ASAE 47:1513-1522

Ordonez-Fernadez R, Carbonnell-Bojollo R-LA (2010) Influence of olive mill waste application on the role of soil as a carbon source or sink. Clim Change 102:625-640

Ouzounidou G, Gervakis G, Gaitis F (2010) Raw and microbiologically detoxified olive mill waste and their impact on plant growth. Terrestrial Aquat Environ Toxicol 4:21-38

Page AL, Miller RH, Keeney DR (1982) Methods of soil analysis. Part 2: chemical and microbiological properties. Agronomy, ASSSA, Madison

Ryan BF, Joiner BL, Cryer JD (2005) MINITAB handbook: updated for release 14, 5th edn. Brooks/Cole, Florence

Saadi I, Laor Y, Raviv M, Shlomit M (2007) Land spreading of olive mill wastewater: effects on soil microbial activity and potential phytotoxicity. Chemosphere 66:75-83

Vagelas I, Kalorizou H, Papachatzis A, Botou M (2009a) Bioactivity of olive oil mill wastewater against plant pathogens and post-harvest diseases. Biotechnol Biotechnol Equip 23(4):1150-1152

Vagelas I, Papachatzis A, Kalorizou H, Wogiatzi E (2009b) Biological control of Botrytis fruit rot (gray mold) on strawberry and red pepper fruits by olive oil mill wastewater. Biotechnol Biotechnol Equip 23:1489-1491

Wu J, Brookes PC (2005) The proportional mineralisation of microbial biomass and organic matter caused by air-drying and rewetting of a grassland soil. Soil Biol Biochem 37:507-515

\subsection{6/2251-7715-2-13}

Cite this article as: Gougoulias et al:: Chemical and biological properties of a sandy loam soil, amended with olive mill waste, solid or liquid form in vitro. International Journal Of Recycling of Organic Waste in Agriculture 2013, 2:13 